\title{
Meta
}

Journal des traducteurs

Translators' Journal

\section{WESTERWEEL, Bart and Theo D'HAEN (Eds.) (1990): Something Understood. Studies in Anglo-Dutch Literary Translation, Amsterdam-Atlanta, GA, Rodopi, 335 p.}

\section{Daniel Slote}

Volume 38, numéro 1, mars 1993

La traduction et l'interprétation dans le nord du Canada

Translation and Interpretation in Northen Canada

URI : https://id.erudit.org/iderudit/004174ar

DOI : https://doi.org/10.7202/004174ar

Aller au sommaire du numéro

Éditeur(s)

Les Presses de l'Université de Montréal

ISSN

0026-0452 (imprimé)

1492-1421 (numérique)

Découvrir la revue

Citer ce compte rendu

Slote, D. (1993). Compte rendu de [WESTERWEEL, Bart and Theo D'HAEN (Eds.) (1990): Something Understood. Studies in Anglo-Dutch Literary Translation, Amsterdam-Atlanta, GA, Rodopi, 335 p.l Meta, 38(1), 123-124.

https://doi.org/10.7202/004174ar d'utilisation que vous pouvez consulter en ligne.

https://apropos.erudit.org/fr/usagers/politique-dutilisation/ 
WESTERWEEL, Bart and Theo D'HAEN (Eds.) (1990): Something Understood. Studies in Anglo-Dutch Literary Translation, Amsterdam-Atlanta, GA, Rodopi, 335 p.

This collection of essays concerns the position of British and American literary studies in the Dutch universities, proposing a number of areas of common ground for the study of British and American literature in a Dutch context. The focal point of the collection is literary translation and various specialists were called upon to contribute. The editors point out, however, that the book is not intended for academic consumption only. This is clear from the variety of topics dealt with, from translations of Shakespeare to subtitling on television, from the difficulties in translating the Song of Songs to the problems of metre and rhyme in translating Dutch poetry, from the translations of Sterne's novels to the collage experiments of the modern Dutch poet H.C. ten Berge. In other words, there is plenty of material here for those interested in the many theoretical and pragmatic ramifications of literary translation.

The prevalent theme in many of the essays is the skepticism of the translator where translation theory is concerned. There are theoretical translation studies, descriptive translation studies and applied translation studies: the point many of the essays makes is that applied translation studies seem to be the only relevant focal point when the "act of translation" occurs, the other areas of translation studies being of great interest assuredly but ultimately of an academic and after-the-fact nature. A section on craftsmen versus academics makes this point quite tellingly.

Theo d'Haen's excellent essay on Gone With the Wind and a poem by Auden ("The Shield of Achilles") reveals the underlying theme of literary snobbery the author deplores in Dutch universities (although the same kind of snobbery is rife in our own universities), i.e. the blessing given by academics to the difficult, complex Auden poem, and the contempt (or patronizing tolerance) of the same group to Mitchell's popular novel. This attitude, d'Haen implies, has been prevalent in Dutch universities for centuries, in that the literature studies and translated in the Netherlands was dependent for its literary worth upon the judgment of a relatively small cenacle of university intellectuals who decided what was "eternal" and suitable for translation, and what was of mere transient interest, hence unworthy of a translator's time or energy.

E.M. Beekman echoes this theme in "Scio/Nescio. Reflections on Translation." Quoting Octavio Paz, Beekman states that translation is "an art of shadows and echoes," and concludes that a perfect translation cannot exist. Translators, like Phaëton, have been warned about trying the impossible but they proceed nevertheless and often get burned. His message is that ultimately, and independently of theory, there should be fidelity to the original text and at the same time fidelity to one's own language. What is the ideal situation for the literary translator? Why, to translate a text for love and money of course!

This collection of essays is somewhat repetitive in theme but eminently readable. The synopsis of the attitude of the Netherlands through the centuries to the works of Shakespeare, for instance, is very revealing in its insights into the enormous - and again, snobbish - influence French critics had on "taste" in Dutch literary circles. Voltaire's repudiation of Shakespeare in his later years caused a complete volte-face in the attitude of the intellectuals of the time and caused them to label his plays as barbarous and inept.

The essay at the end of the book on literary translation theory is interesting in the sense that even "equivalence" becomes the equivalent - no pun intended - of "pragmatic success." 
The bibliographies after each essay are very useful, quite illuminating in their detailed references to Dutch specialists who are not too well known outside of the Netherlands, and yet who are doing important work in the ever-expanding field of translation studies.

DANIEL SLOTE Université de Montréal, Montréal, Canada 